\title{
Notifikasi Aksi Korporasi Sebagai Instrumen Hukum Pencegah Praktik Monopoli dan Persaingan Usaha Tidak Sehat
}

\author{
Hottua Manalu \\ Fakultas Hukum Universitas Jambi \\ hottuamanalu6@gmail.com
}

\section{Abstract}

This article discusses about corporation action notification on the competition law perspective. Corporation action notification is a notification obligations by the business actor to the Business Competition Supervisory Commision about corporation action in the form of incorporation, fusion, or company share acquition that caused asset value or sales value is ecxceed specific value. This article concluded that notification is an important instrument to prevent monopolistic practices and unfair competition, because a corporation action has an influence towards business competition, that can increase market concentration and this can make a product price more higher and business actor's market power become bigger so that can threatening small business actor. However, the notification nowadays applied in Indonesia is notification to the commission after the corporation action has been done, or as known as post-notification, actually is not effective to prevent monopolistic practices and unfair competition, because of the notification is delivered after the corporation action has been done, so that in case the Commission assess that the corporation action is causing monopolistic practices and unfair competition then the revocation is complicated. Therefore, this article is encouraging notification to be done before corporation action is started, as known as pra-notification, so monopolistic practices and unfair competition possibility can be detected earlier and can be prevented.

Keywords: notification; corporation action; competition law; Business Competition Supervisory Commision. 


\section{Hottua Manalu}

Abstrak

Artikel ini membahas notifikasi aksi korporasi dalam perspektif hukum persaingan usaha. Notifikasi aksi korporasi adalah kewajiban pemberitahuan oleh pelaku usaha kepada Komisi Pengawas Persaingan Usaha atas aksi korporasibaik dalambentuk penggabungan, peleburan, maupun pengambilalihan saham perseroan yang berakibat nilai aset dan atau nilai penjualannya melebihi jumlah tertentu. Artikel ini menyimpulkan, notifikasi merupakan instrumen penting dalam mencegah praktik monopoli dan persaingan usaha tidak sehat, dikarenakan aksi korporasi berpengaruh terhadap persaingan usaha, yaitu menyebabkan bertambahnya konsentrasi pasar yang dapat menyebabkan harga produk semakin tinggi dan kekuatan pasar pelaku usaha menjadi semakin besar sehingga dapat mengancam pebisnis kecil. Namun demikian, notifikasi yang saat ini berlaku di Indonesia, yaitu pemberitahuan kepada Komisi setelah aksi korporasi selesai dilakukan, atau yang dikenali dengan post-notifikasi, sesungguhnya tidak efektif mencegah praktik monopoli dan persaingan usaha tidak sehat, dikarenakan notifikasi disampaikan setelah aksi korporasi selesai dilakukan, sehingga dalam hal Komisi menilai aksi korporasi menyebabkan praktik monopoli dan persaingan usaha tidak sehat maka pembatalan jelas mengalami kerumitan. Oleh karenanya, artikel ini mendorong notifikasi dilakukan sebelum aksi korporasi dilakukan, yang disebut dengan pra-notifikasi, agar kemungkinan terjadinya praktik monopoli dan persaingan usaha tidak sehat diketahui sejak dini dan dapat dicegah.

Kata Kunci: notifikasi; aksi korporasi; hukum persaingan usaha; Komisi Pengawas Persaingan Usaha.

\section{A. Pendahuluan}

Artikel ini membahas notifikasi aksi korporasi ditelaah berdasarkan hukum persaingan usaha. Dalam hukum persaingan usaha, korporasi yang melakukan aksi korporasi meliputi penggabungan atau merger, peleburan atau konsolidasi, dan pengambilalihan atau akuisisi, ${ }^{1}$

1 Dalam hukum perusahaan Indonesia, istilah penggabungan, peleburan, dan pengambilalihan digunakan dalam Undang-Undang Nomor 40 Tahun 2007 tentang Perseroan Terbatas (UU PT Tahun 2007); sementara istilah merger, konsolidasi, dan akuisisi digunakan Undang-Undang Nomor 10 Tahun 1998 tentang Perubahan atas Undang-Undang Nomor 7 Tahun 1992 
diharuskan untuk memberitahu (notifikasi) aksi korporasi tersebut kepada lembaga yang mengawasi persaingan usaha, yang di Indonesia adalah Komisi Pengawas Persaingan Usaha (KPPU). ${ }^{2}$ Pemberitahuan atau notifikasi tersebut dimaksudkan agar aksi korporasi tidak berdampak buruk bagi iklim persaingan usaha yang sehat. Dalam artikel ini dibahas, bagaimanakah notifikasi itu semestinya dilakukan oleh korporasi yang melakukan aksi korporasi, sehingga tidak justru malah menyebabkan praktik monopoli dan persaingan usaha tidak sehat.

Di Indonesia, ketentuan mengenai notifikasi aksi korporasi diatur dalam Undang-Undang Nomor 5 Tahun 1999 tentang Larangan Praktek Monopoli dan Persaingan Usaha Tidak Sehat (UU Persaingan Usaha), ${ }^{3}$ dan diaturlebih lanjut dalam Peraturan Pemerintah Nomor 57

tentang Perbankan (UU Perbankan Tahun 1998). Istilah penggabungan pada dasarnya sama dengan merger, peleburan sama artinya dengan konsolidasi, dan pengambilalihan sama maksudnya dengan akuisisi. Oleh karenanya istilah-istilah tersebut seringkali digunakan secara bergantian.

2 KPPU merupakan lembaga negara independen yang dibentuk berdasarkan Keputusan Presiden Nomor 75 Tahun 1999 sebagaimana telah diubah dengan Peraturan Presiden Republik Indonesia Nomor 80 Tahun 2008 tentang Perubahan atas Keputusan Presiden Republik Indonesia Nomor 75 Tahun 1999 tentang Komisi Pengawas Persaingan Usaha yang berfungsi sebagai pengawas pelaksanaan UU Persaingan Usaha serta memiliki tugas dan wewenang untuk melakukan Penyidikan, Penuntutan, dan sekaligus Pengadilan sebagaimana diatur dalam Pasal 35 dan Pasal 46 UU Persaingan Usaha. Muhamad Sadi Is, Hukum Persaingan Usaha di Indonesia KPPU Sebagai Upaya Penguatan Lembaga Komisi Pengawas Persaingan Usaha (Malang: Setara Press, 2016), hlm. 2.

3 Lahirnya UU Persaingan Usaha merupakan produk hukum buah reformasi yang disahkan oleh Presiden B.J. Habibie, yang mulai berlaku tanggal 5 Maret 2000 terhitung 1 (satu) tahun sejak tanggal diundangkan. Faktor pendorong kemunculan Undang-Undang ini dikarenakan adanya tindakan pemerintah Indonesia untuk meminta bantuan pencairan dana sebesar US\$ 43 Milyar kepada IMF (Internasional Monetary Fund) yang mensyaratkan Indonesia harus segera memiliki peraturan mengenai Persaingan Usaha yakni melalui Letter of Intent (Lol) dan Supplementary Memorandum yang ditandatangani oleh Indonesia dengan pihak IMF di Jakarta pada tanggal 15 Januari 1998. Dana tersebut digunakan untuk pemulihan ekonomi akibat krisis moneter 1998. Di balik itu, sebenarnya, keinginan Indonesia untuk memiliki UU Antimonopoli sudah ada sejak lama, karena faktor political will yang tidak mendukung dan sistem pemerintahan yang cenderung otoriter sehingga menghambat lahirnya UU ini. Dengan adanya peminjaman dana 
Tahun 2010 tentang Penggabungan atau Peleburan Badan Usaha dan Pengambilalihan Saham Perseroan Perusahaan yang Dapat Mengakibatkan Praktek Monopoli dan Persaingan Usaha Tidak Sehat (PP No. 57 Tahun 2010) dan Peraturan Komisi Pengawas Persaingan Usaha Nomor 2 Tahun 2013 tentang Perubahan Ketiga atas Peraturan Komisi Pengawas Persaingan Usaha Nomor 13 Tahun 2010 tentang Pedoman Pelaksanaan tentang Penggabungan atau Peleburan Badan Usaha dan Pengambilalihan Saham Perusahaan yang Dapat Mengakibatkan Terjadinya Praktik Monopoli dan Persaingan Usaha Tidak Sehat (Perkom No. 2 Tahun 2013). Dalam UU Persaingan Usaha diatur bahwa perusahaan yang melakukan aksi korporasi dan berakibat nilai aset dan atau nilai penjualannya melebihi jumlah tertentu ${ }^{4}$ wajib memberitahu kepada KPPU selambat-lambatnya 30 hari sejak aksi korporasi itu dilakukan. ${ }^{5}$ Ketentuan demikian menunjukkan bahwa notifikasi dilakukan setelah aksi korporasi selesai dilaksanakan, atau disebut post-notifikasi. Ketentuan serupa diperkuat dalam PP No. 57 Tahun $2010,{ }^{6}$ namun ditambah dengan kemungkinan dilakukannya konsultasi sebelum aksi korporasi dilaksanakan. ${ }^{7}$

kepada IMF memaksa Indonesia harus memiliki UU Antimonopoli. Susanti Adi Nugroho, Hukum Persaingan Usaha di Indonesia dalam Teori dan Praktik serta Penerapan Hukumnya (Jakarta: Prenadamedia Group, cetakan ketiga, 2018), hlm. 13-16.

4 Dalam PP No. 57 Tahun 2010 disebutkan, batas nilai aset ini adalah 2,5 triliun rupiah dan batas nilai penjualan 5 triliun rupiah (Pasal 5 ayat [2]); sedangkan untuk usaha di bidang perbankan, batas nilai aset tersebut adalah 20 triliun rupiah (Pasal 5 ayat [3]).

5 Pasal 29 ayat (1) UU Persaingan Usaha: "Penggabungan atau peleburan badan usaha, atau pengambilalihan saham sebagaimana dimaksud dalam Pasal 28 yang berakibat nilai aset dan atau nilai penjualannya melebihi jumlah tertentu, wajib diberitahukan kepada Komisi, selambat-lambatnya 30 (tiga puluh) hari sejak tanggal penggabungannya, peleburan atau pengambilalihan tersebut".

6 Pasal 5 ayat (1) PP No. 57 Tahun 2010: "Penggabungan Badan Usaha, Peleburan Badan Usaha, atau Pengambilalihan saham perusahaan lain yang berakibat nilai aset dan/atau nilai penjualannya melebihi jumlah tertentu wajib diberitahukan secara tertulis kepada Komisi paling lama 30 (tiga puluh) hari kerja sejak tanggal telah berlaku efektif secara yuridis Penggabungan Badan Usaha, Peleburan Badan Usaha, atau Pengambilalihan saham perusahaan”.

7 Pasal 10 ayat (1) PP No. 57 Tahun 2010: "Pelaku Usaha yang akan 
Notifikasi sesudah aksi korporasi selesai dilaksanakan ini dalam perkembangannya menimbulkan permasalahan, yaitu pertama, berpotensi merugikan pelaku usaha karena aksi korporasi yang sudah selesai dilaksanakan tersebut dapat dibatalkan oleh KPPU jika dinilai dapat mengakibatkan praktik monopoli dan atau persaingan usaha tidak sehat. ${ }^{8}$ Bagi pelaku usaha, terutama yang sudah menyelesaikan aksi korporasi, notifikasi demikian menyebabkan tidak adanya kepastian hukum, karena bisa saja dalam perkembangannya dibatalkan oleh KPPU. ${ }^{9}$ Kedua, notifikasi aksi korporasi pada dasarnya bertujuan untuk mencegah ${ }^{10}$ timbulnya praktik monopoli dan persaingan

melakukan Penggabungan Badan Usaha, Peleburan Badan Usaha, atau Pengambilalihan saham perusahaan lain yang berakibat nilai aset dan/atau nilai penjualannya melebihi jumlah tertentu sebagaimana dimaksud dalam Pasal 5 ayat (2) dan ayat (3) dapat melakukan konsultasi secara lisan atau tertulis kepada Komisi”.

8 Dalam Pasal 47 ayat (2) huruf 2 PP No. 57 Tahun 2010 disebutkan bahwa sanksi administratif yang dapat dijatuhkan oleh KPPU adalah "penetapan pembatalan atas penggabungan atau peleburan badan usaha dan pengambilalihan”.

9 Meski demikian, tentu saja akan sangat sulit untuk membatalkan proses aksi korporasi yang sudah berlangsung. Hal demikian pernah terjadi dalam Putusan KPPU Nomor 07 / KPPU-L/ 2007 tentang akuisisi Temasek terhadap Telkom dan Indosat yang menyatakan pembatalkan aksi korporasi namun kemudian tidak dikuatkan dalam amar putusan Mahkamah Agung pada tahap kasasi.

10 Sebetulnya, Pasal 29 ayat (1) UU Persaingan Usaha tentang notifikasi aksi korporasi merupakan tipe norma hukum tunggal, yang artinya ia hadir tanpa norma yang mengatur mengenai sanksi hukum. Sehubungan dengan itu, Penulis meyakini hadirnya norma tentang notifikasi difungsikan untuk mencegah terjadinya praktik monopoli dan persaingan tidak sehat yang disebabkan oleh efek aksi korporasi. Hal demikian didasari oleh teori penafsiran holistik yakni penafsiran hukum yang mengaitkan suatu naskah hukum dengan konteks keseluruhan jiwa dari naskah tersebut (lihat Jimly Asshiddiqie, Pengantar Ilmu Hukum Tata Negara (Depok: Rajawali Pers, cetakan kesembilan, 2017), hlm. 223) maka Pasal 29 memiliki kaitan erat dengan Pasal 3 huruf c UU Persaingan Usaha, yang mana salah satu tujuan pembentukan UU Persaingan Usaha adalah mencegah praktik monopoli dan atau persaingan usaha tidak sehat yang ditimbulkan oleh pelaku usaha. Dari 53 pasal dalam UU tersebut, Penulis menemukan satu-satunya pasal yang berfungsi sebagai instrumen hukum untuk mencegah praktik monopoli hanya Pasal 29 ayat (1) UU Persaingan Usaha. Bahkan, Pasal 29 tersebut dalam pemahaman Penulis dapat dikatakan sebagai pasal "pengunci" karena selain karakter UU ini dikenal bersifat larangan (negasi) ternyata 
usaha tidak sehat. Tujuan demikian akan sulit terwujud disebabkan notifikasi baru dilakukan sesudah pelaku usaha menyelesaikan aksi korporasinya. ${ }^{11}$

Artikel ini, dengan membedah empat putusan KPPU terkait notifikasi aksi korporasi sebagai latar utamanya di antaranya; Putusan KPPU Nomor 07/KPPU-L/2007 tentang akuisisi Temasek terhadap Telkom dan Indosat, Putusan KPPU Nomor 09/KPPU-L/2009 tentang akuisisi PT. Alfa Retailino oleh PT. Carrefour Indonesia, Putusan KPPU Nomor 08/KPPU-M/2012 mengenai keterlambatan pemberitahuan pengambilalihan saham PT. Andalan Satria Lestari oleh PT. Bumi Kencana Eka Sejahtera, dan Putusan KPPU Nomor 07/KPPU-M/2014 tentang keterlambatan pemberitahuan pengambilalihan saham PT. HD Finance, Tbk. oleh PT. Tiara Marga Trakindo. Kemudian menganalisis bagaimana sebenarnya mekanisme notifikasi (pemberitahuan) yang ideal untuk diterapkan di Indonesia. Dalam membahas persoalan tersebut, artikel ini setelah bagian ini membahas terlebih dahulu aksi korporasi dan pengaruhnya terhadap persaingan usaha, dan selanjutnya membandingkan konsekuensi yang ditimbulkan jika notifikasi dilakukan sebelum dan sesudah aksi korporasi.

\section{B. Aksi Korporasi dan Pengaruhnya terhadap Persaingan Usaha}

Dalam ekonomi, pelaku usaha sejatinya berupaya mencari keuntung-

memiliki karakter preventif yakni dalam Pasal 29. Jika dipahami lebih dalam lagi, kewajiban notifikasi dapat menjadi kunci keberhasilan terciptanya atmosfer persaingan usaha yang sehat di Indonesia, karena dapat mengcounter pelaku usaha untuk bekerja sama yang biasanya disiasati melalui transaksi aksi korporasi untuk melakukan praktik monopoli. Kalaupun hanya terdapat satu pelaku usaha yang melakukan praktik monopoli, tidak menutup kemungkinan ia berasal dari proses merger atau konsolidasi.

11 Konsekuensi demikian terlihat dalam Putusan KPPU Nomor 09/KPPUL/2009 tentang praktik monopoli dan persaingan usaha tidak sehat atas akuisisi PT. Alfa Retailindo oleh PT. Carrefour Indonesia, yang memperlihatkan adanya penyalahgunaan posisi dominan yang menimbulkan persaingan usaha tidak sehat. 
an. ${ }^{12}$ Salah satu tindakan yang bi(a)sa dilakukan pelaku usaha dalam rangka memaksimalkan keuntungan adalah dengan membentuk jaringan dan perikatan dengan sesama pelaku usaha. ${ }^{13}$ Aksi korporasi pada dasarnya adalah bagian dari cara pelaku usaha untuk memperkuat dominasinya dalam mengembangkan kegiatan usaha. ${ }^{14}$

Istilah aksi korporasi merujuk pada tindakan pelaku usaha dalam hal ini badan usaha korporasi untuk bergabung dengan korporasi lainnya atau membentuk korporasi baru yang lebih besar atau justru mengambilalih badan usaha lainnya. Istilah demikian dalam hukum perusahaan dikenali dengan penggabungan atau merger, ${ }^{15}$ peleburan atau konsolidasi, dan pengambilalihan atau akuisisi. Penggabungan atau merger adalah tindakan korporasi untuk menggabungkan diri dengan korporasi lainnya, yang berarti korporasi yang menggabungkan diri menjadi berakhir eksistensinya sementara korporasi tempat

12 Pivi Princifal Yosefa Tarigan dan Wahyu Ario Pratomo, "Analisis Dampak Merger dan Akuisisi Terhadap Abnormal Return dan Kinerja Keuangan Pada Perusahaan yang Terdaftar di Bursa Efek Indonesia”, Jurnal Ekonomi dan Keuangan, 3, 3 (2015), hlm. 200.

13 Megawati Rihi dan I Ketut Sudantra, "Merger dalam Hubungannya dengan Persaingan Usaha Tidak Sehat", Kertha Semaya: Journal Ilmu Hukum, 1, 4 (2013), hlm. 3.

14 Beberapa motivasi lain pelaku usaha melakukan aksi korporasi selain keuntungan adalah meningkatkan kesejahteraan pemegang saham, sinergi, pertimbangan pajak, membeli aset di bawah biaya penggantian, diversifikasi, insentif bagi manajer dan break up value. Lihat Sutrisno dan Sumarsih, "Dampak Jangka Panjang Merger dan Akuisisi Terhadap Pemegang Saham di BEJ Perbandingan Akuisisi internal dan Eksternal”, Jurnal Akuntansi dan Auditing Indonesia, 8, 2 (2004), hlm. 190.

15 Merger memiliki empat tipe yakni horizontal merger yaitu terjadi apabila satu perusahaan menggabungkan diri dengan perusahaan lain dalam jenis bisnis yang sama, vertical merger yaitu merger yang terjadi apabila satu perusahaan menggabungkan diri dengan perusahaan lain yang memiliki keterkaitan antara input-output, congeneric merger yaitu merger yang terjadi apabila satu perusahaan menggabungkan diri dengan perusahaan lain dalam jenis bisnis/industri yang sama, tetapi tidak memproduksi produk yang sama maupun tidak ada keterkaitan supplier, conglomerate merger yakni merger yang terjadi apabila satu perusahaan menggabungkan diri dengan perusahaan lain dalam jenis bisnis/industri yang berbeda. Utoyo Widayat, "Beberapa Dimensi Merger dan Akuisisi", Akuntansi Krida Wacana, 5, 3 (2005), hlm. 274-275. 
bergabung akan menjadi lebih besar:; ${ }^{16}$ peleburan atau konsolidasi adalah tindakan dua atau lebih korporasi untuk meleburkan diri membentuk korporasi yang baru dan dengan demikian eksistensi korporasi yang sebelumnya menjadi berakhir; ${ }^{17}$ pengambilalihan atau akuisisi adalah tindakan korporasi untuk mengambil alih saham korporasi lainnya sehingga beralih pengendaliannya. ${ }^{18}$

Aksi korporasi yang meliputi penggabungan, peleburan, dan pengambilalihan, dengan demikian merupakan bagian dari upaya korporasi untuk memperkuat jaringan atau membesarkan kegiatan usaha yang dilakukan. Hal ini bisa terjadi karena jika semula terdapat dua atau lebih entitas korporasi dalam bidang usaha tertentu dan kemudian bergabung melalui aksi korporasi, maka jelas mereka akan semakin mudah menguasai pasar dan memperkuat posisinya menjadi lebih unggul di antara para pesaingnya.

Selain sebagai trik memaksimalkan keuntungan, aksi korporasi

16 Penggabungan menurut UU PT Tahun 2007 adalah "perbuatan hukum yang dilakukan satu perseroan atau lebih untuk menggabungkan diri dengan perseroan lainnya yang telah ada yang mengakibatkan aktiva dan pasiva dari perseroan yang menggabungkan ini beralih karena hukum kepada perseroan yang menerima penggabungan dan selanjutnya status badan hukum perseroan yang menggabungkan diri berakhir karena hukum” (Pasal 1 angka 9). Dalam UU Perbankan Tahun 1998, istilah yang digunakan untuk penggabungan adalah merger, yaitu "penggabungan dari dua bank atau lebih, dengan cara tetap mempertahankan berdirinya salah satu bank dan membubarkan bank-bank lainnya dengan atau tanpa melikuidasi” (Pasal 1 angka 25).

17 Peleburan adalah "perbuatan hukum yang dilakukan dua perseroan atau lebih untuk meleburkan diri dengan cara mendirikan satu perseroan baru yang karena hukum memperoleh aktiva dan pasiva dari perseroan yang meleburkan diri dan status badan hukum perseroan yang meleburkan diri berakhir karena hukum" (Pasal 1 angka 10 UU PT Tahun 2007). Dalam UU Perbankan, istilah yang digunakan untuk peleburan adalah konsolidasi, yaitu "penggabungan dari dua bank atau lebih, dengan cara mendirikan bank baru dan membubarkan bank-bank tersebut dengan atau tanpa melikuidasi” (Pasal 1 angka 26).

18 Pengambilalihan adalah "perbuatan hukum yang dilakukan oleh badan hukum atau orang perseorangan untuk mengambil alih saham perseroan yang mengakibatkan beralihnya pengendalian atas perseroan tersebut" (Pasal 1 angka 11 UU PT Tahun 2007). Dalam UU Perbankan, istilah yang digunakan untuk pengambilalihan adalah akuisisi, yaitu "pengambialihan kepemilikan suatu bank" (Pasal 1 angka 27). 
juga dapat menciptakan efisiensi yang mampu menekan biaya produksi suatu perusahaan. ${ }^{19}$ Meskipun begitu, teori ekonomi mengatakan bahwa ketika aksi korporasi marak dilakukan oleh pelaku usaha maka secara otomatis jumlah pelaku usaha dalam pasar bersangkutan $^{20}$ semakin sedikit, yang pada akhirnya berpotensi terjadi kolusi di antara para pelaku usaha. ${ }^{21} \mathrm{Hal}$ ini sejalan ketika dikorelasikan pada sifat dunia bisnis yang pada pokoknya mencari keuntungan maksimal dalam menjalankan usahanya. ${ }^{22}$ Dengan kata lain, kolusi dalam rangka mencari keuntungan tersebut diperoleh dengan mengabaikan kesejahteraan rakyat (konsumen) ${ }^{23}$

Hukum persaingan usaha ${ }^{24}$ lahir sebagai upaya menciptakan persaingan usaha yang sehat. UU Persaingan Usaha merupakan produk hukum untuk menciptakan iklim persaingan usaha yang

19 Rachmadi Usman, Hukum Persaingan Usaha di Indonesia (Jakarta: Sinar Grafika, 2013), hlm. 635.

20 Pasal 1 angka 10 UU Persaingan Usaha: "Pasar bersangkutan adalah pasar yang berkaitan dengan jangkauan atau daerah pemasaran tertentu oleh pelaku usaha atas barang dan atau jasa yang sama atau sejenis atau substitusi dari barang dan atau jasa tersebut".

21 Rachmadi Usman, Hukum Persaingan Usaha di Indonesia, hlm. 634.

22 Nugroho, Hukum Persaingan Usaha di Indonesia, hlm. 441.

23 Veblen dalam bukunya The Theory of Business Enterprise, melalui analisanya atas perilaku pengusaha di Amerika mengatakan bahwa terdapat pergeseran perilaku pengusaha yang memperoleh keuntungan melalui berbagai cara tanpa memperdulikan nasib orang lain, disebutnya sebagai pengusaha pemangsa (predator). Veblen melihat cara yang biasa dilakukan pengusaha untuk mendapatkan laba sebesar-besarnya adalah dengan kongkalingkong dengan penguasa, mematikan pesaing dengan cara akuisisi, membanting harga, setelah pesaing mati, biasanya mereka kembali menaikkan harga dan bebas menentukan harga. Lihat Deliarnov, Perkembangan Pemikiran Ekonomi Edisi Ketiga, (Jakarta: Rajawali Pers, cetakan kesembilan, 2015), hlm. 148151.

24 Hukum persaingan usaha (competition law) sejatinya merupakan pengembangan dari hukum ekonomi (economic law) yang memiliki karakter tersendiri. Sebagaimana diketahui bahwa salah satu karakteristiknya adalah bersifat fungsional dengan meniadakan pembedaan antara hukum publik dan hukum privat yang selama ini dikenal. Maka, hukum persaingan usaha sebagai bagian dari hukum ekonomi juga dengan sendirinya memuat aspek hukum privat dan hukum publik. Rachmadi Usman, Hukum Acara Persaingan Usaha di Indonesia, hlm. 1-4. Sama halnya dengan aksi korporasi terdapat peristiwa perdata di dalamnya namun peristiwa tersebut dapat menimbulkan akibat publik sehingga perlu pengawasan dari KPPU. 
sehat yang bertujuan menyeimbangkan kepentingan antara pelaku usaha dan kepentingan umum (rakyat). ${ }^{25} \mathrm{UU}$ ini mendorong pelaku usaha untuk meningkatkan kualitas produk, melakukan inovasi agar bisa bersaing di pasar, dan terlindunginya kesempatan berusaha yang sama antar pelaku usaha. Di sisi lain, rakyat mendapatkan harga yang terjangkau, produk yang berkualitas, serta memiliki banyak pilihan di pasar.

Namun tujuan ini akan terhambat jika aksi korporasi tidak dikontrol dengan baik. Setidaknya ada dua efek negatif dari aksi korporasi terhadap persaingan usaha, yakni terciptanya atau bertambahnya konsentrasi pasar yang dapat menyebabkan harga produk semakin tinggi dan kekuatan pasar (market power) pelaku usaha menjadi semakin besar yang dapat mengancam pebisnis kecil. ${ }^{26}$ Dengan kata lain, pelaku usaha yang semula berdiri sendiri kemudian bergabung (merger) memungkinkan pelaku usaha dengan mudah mengatur harga barang, kuantitas dan kualiatas produk, serta dengan mudah menghalangi pelaku usaha lain untuk masuk ke pasar yang pada akhirnya berujung pada terdistorsinya mekanisme pasar yang wajar.

Contoh dampakaksikorporasi ini adalah terciptanya kesepakatan eksplisit maupun implisit atas harga yang ditetapkan. ${ }^{27}$ Saat barang atau jasa memiliki kesamaan harga antara pelaku usaha di pasar

25 Jimat Jojiyon Suhara mengatakan keseimbangan antara kepentingan pelaku usaha dan kepentingan umum sebagaimana tercantum dalam Pasal 2 UU Persaingan Usaha dinilai kabur karena secara gramatikal kalimat tersebut tidak ditemukan dalam Pasal 33 ayat (4) UUD NRI 1945. Hal ini menyebabkan banyak yang menafsirkan pengertiannya sama dengan prinsip dasar dari hukum antitrust di Amerika dan negara-negara pengikutnya yaitu keseimbangan antara pelaku usaha dan konsumen. Jadi, kepentingan umum dipersamakan dengan "konsumen". Jika ditelisik pengaturan dalam UU Persaingan Usaha sangat mirip bahkan terkesan mencontoh hukum persaingan negara lain khususnya Jerman, yang mana negara ini juga dipengaruhi oleh hukum negara Amerika. Rachmadi Usman, Hukum Acara Persaingan Usaha di Indonesia, hlm. 17. Penulis memakai kata "rakyat" karena kata tersebut tercantum jelas dalam Pasal 3 UU Persaingan Usaha yang mana rakyat merupakan bagian dari kepentingan umum itu sendiri.

26 Suyad Margono, Hukum Anti Monopoli (Jakarta: Sinar Grafika, cetakan kedua, 2013), hlm. 130.

27 Andi Fahmi Lubis dkk, Hukum Persaingan Usaha Antara Teks \& Konteks, hlm. 198. 
apalagi kalau barang tersebut tidak ada substitusi atau penggantinya, maka masyarakat (konsumen) tidak mempunyai pilihan untuk tidak membeli, yang sebetulnya rakyat sedang dieksploitasi melalui execcive pricing demi keuntungan segelintir pelaku usaha.

Ada lima alasan mengapa aksi korporasi dapat mengarah pada persaingan usaha tidak sehat. Pertama, pemanfaatan sumber-sumber ekonomi menjadi tidak ekonomis. Hal ini dikarenakan sedikitnya pelaku usaha sehingga menyebabkan mereka tidak terpacu untuk berkompetisi menciptakan produk yang paling efisien dengan harga yang ekonomis. Pelaku usaha cenderung beranggapan berapa pun harga dan kualitas produk, akan tetap dibeli oleh konsumen. Kedua, pelakuusahaberpotensimenekankonsumendenganmengaturjumlah produksi dan peredaran barang yang mengakibatkan kelangkaan dan pada akhirnya harga produk meninggi. Ketiga, inovasi-inovasi produk menjadi terhambat yang mengakibatkan daya saing terhadap pelaku usaha negara lain rendah. ${ }^{28}$ Keempat, instabilisasi atas supply produk di masyarakat, sehingga ketika masalah muncul secara internal pada perusahaan dominan akan mengganggu produksi secara nasional. Kelima, kesejahteraan ekonomi masyarakat menjadi terhambat yang berdampak pada melesunya pembangunan nasional. Poin terakhir ini merupakan dampak akhir yang disebabkan karena empat poin yang telah diuraikan di atas terjadi. ${ }^{29}$

Adanya pemusatan kekuatan pasar sebagai akibat aksi korporasi dapat dilihat dalam akuisisi saham PT. Alfa Retailindo oleh PT. Carrefour Indonesia pada tahun 2008. Dengan mengakuisisi saham Alfa sebesar $75 \%$, Carrefour memiliki kendali pada Alfa. ${ }^{30}$ Bergabungnya kedua peritel tersebut menyebabkan kekuatan pasar

28 Meskipun hal ini juga bisa menjadi simalakama bagi pelaku usaha, sebab kalau suatu saat pasar bebas dibuka maka pelaku usaha yang tidak inovatif dan efisien akan tenggelam oleh kehadiran produk luar negeri yang lebih inovatif.

29 Nugroho, Hukum Persaingan Usaha di Indonesia, hlm. 471.

30 Devi Meyliana, Hukum Persaingan Usaha Studi Konsep Pembuktian Terhadap Perjanjian Penetapan Harga dalam Persaingan Usaha (Malang: Setara Press, 2013), hlm. 40. 
Carrefour semakin meningkat. ${ }^{31}$ Dalam perkembangannya, Carrefour menyalahgunakan kekuatan pasar yang dimilikinya. Hal ini ditandai dengan menekan para pemasok melalui penerapan syaratsyarat perdagangan(trading terms). ${ }^{32}$ Dengan trading terms yang tidak wajar, Carrefour pada tahun $2008^{33}$ memeroleh pendapatan sebesar 1,3 triliun rupiah hanya dari trading terms saja, paling unggul daripada pesaing ritel lainnya.

Meskipun trading terms yang ditawarkan Carrefour memberatkan pemasok, ${ }^{34}$ akan tetapi pemasok terpaksa untuk memasok barang kepada Carrefour. Hal demikian terjadi, karena pemasok tidak mempunyai pilihan lain, mengingat Carrefour merupakan

31 Pengukuran kekuatan pasar dapat dilakukan dengan menilai ukuran atau skala usaha pelaku usaha dibandingkan ukuran/skala usaha pelaku usaha lainnya. Ukuran tersebut dapat didasarkan pada nilai penjualan, kapasitas produksi, maupun kapasitas penjualan yang dapat diukur dari luas lahan penjualan. Berdasarkan analisis KPPU, pangsa lahan Carrefour selalu memiliki pangsa lahan tertinggi di enam wilayah dari tujuh wilayah di Jakarta, yaitu: Carrefour ex Alfa Sunter, Carrefour Express Lodan, Carrefour Express Menteng, Carrefour Express Tendean, Carrefour Express Meruya Ilir, Carrefour Express Kebayoran. Lihat Putusan KPPU Nomor 09/KPPUL/2009, hlm. 85.

32 Trading terms adalah harga yang dibayar oleh pemasok kepada peritel untuk memperoleh jasa-jasa terkait dengan seluruh aktivitas peritel dalam melakukan penjualan barang-barangnya. Trading terms tersebut berupa potongan yang dilakukan oleh peritel dari nilai penjualan pemasok kepada peritel. Istilah trading terms sebelumnya tidak pernah dikenal dalam perdagangan ritel modern. Carrefour merupakan ritel asal Perancis pertama kali di Indonesia yang memperkenalkan trading terms yang kemudian diikuti oleh peritel-peritel lainnya.

33 Sebelumnya, PT. Carrefour Indonesia pernah terjerat kasus yang serupa pada tahun 2005. Carrefour dikenakan Pasal 25 ayat (1) huruf a UU Persaingan Usaha tentang penetapan syarat perdagangan (trading terms). Lihat Putusan KPPU Nomor 02 / KPPU-L/ 2005.

34 Dari beberapa media terdapat keluhan yang muncul dari pihak pemasok baik Carrefour maupun Alfa terhadap keberadaan trading term tersebut. Salah satunya seperti yang ditulis oleh harian Bisnis Indonesia 10 Juni 2008 yang memuat judul 'Peritel dituding akali syarat perdagangan'. Beberapa hal yang dikeluhkan adalah menaikkan persentase biaya jenis syarat perdagangan yang diperbolehkan dan membuat sejumlah perincian pada setiap jenis syarat perdagangan yang diperkenalkan. Lihat Putusan KPPU Nomor 09/KPPU-L/2009, hlm. 118. 
peritel terbesar di Jakarta. ${ }^{35}$ Tidak hanya itu, Carrefour juga memaksa para pemasok untuk memasok barang ke Alfa (tying in), yang mana penerapan besaran trading terms sama seperti yang diterapkan di Carrefour. Logikanya, Carrefour masih dimungkinkan untuk menaikkan harga jual barang tersebut kepada konsumen akhir dan memeroleh margin keuntungan. Sehingga Carrefour dapat memeroleh keuntungan dari selisih harga beli barang dari pemasok dan harga jual kepada konsumen, ${ }^{36}$ ditambah lagi dengan potongan trading terms. Tidak hanya itu, Carrefour juga memberlakukan klausul additional conditional rebate ${ }^{37}$ kepada pemasok yang mana Carrefour memberlakukan penghitungan pencapaian penjualan dari seluruh gerai Carrefour dan gerai Alfa sehingga target penjualan akan mudah didapat. Berdasarkan hal di atas, setidaknya Carrefour dan Alfa mendapat keuntungan tidak wajar melalui empat item, yaitu trading terms, selisih harga beli barang dari pemasok, selisih harga jual, dan additional conditional rebate.

Berkaca dari kasus tersebut, terlihat jelas bahwa aksi korporasi memiliki dampak yang signifikan terhadap iklim persaingan usaha. Kasus tersebut menunjukkan bahwa pemasok menjadi pihak yang sangat dirugikan akibat aksi korporasi. Dalam hal ini, konsumen justru sama sekali tidak dirugikan, karena konsumen dimungkinkan mendapatkan harga barang yang cenderung murah, yang kemudian hal ini berpengaruh pada peritel lain yang akan sulit untuk bersaing harga dengan Carrefour.

Dalam jangka panjang, keadaan demikian juga bisa berdampak buruk pada konsumen, karena para pemasok perlahan akan menaikkan harga barang penjualan kepada Carrefour untuk menutupi biaya trading terms yang berdampak pada kenaikan harga barang. Kemudian, pesaing ritel Carrefour lainnya dimungkinkan mengikuti

35 BAP Ketua Gabungan Elektronik (GABEL), Putusan KPPU Nomor 09/ KPPU-L/2009, hlm. 110.

36 Lihat Putusan KPPU Nomor 09/KPPU-L/2009.

37 Conditional rebate dapat diartikan sebagai potongan harga suatu barang dari pemasok yang dinikmati Carrefour dari harga belinya kepada pemasok apabila penjualan barang tersebut mencapai atau melebihi target penjualan. Putusan KPPU Nomor 09/KPPU-L/2009, hlm. 128. 
pola besaran trading terms dan/atau harga barang Carrefour ${ }^{38}$ dengan tujuan agar mampu tetap bersaing sehingga konsumen akhir yang mengalami kerugian terbesar akibat perilaku tersebut. ${ }^{39} \mathrm{Jika}$ keadaan tersebut dibiarkan maka akan menimbulkan kerusakan pasar yang mendistorsi hukum permintaan dan penawaran, yang mana pihakpihak yang terlibat baik peritel dan pemasok akan kehilangan jati dirinya dalam melakukan pelayanan terbaik kepada konsumen (masyarakat). Dengan kata lain, sebetulnya bagi siapapun yang melakukan praktik persaingan usaha yang tidak sehat sejatinya cepat atau lambat pada akhirnya akan menghancurkan dirinya sendiri yang muaranya mengganggu stabilititas ekonomi negara.

Dengan demikian, aksi korporasi sesungguhnya bisa berdampak positif terutama terhadap pelaku usaha namun juga bisa berdampak negatif terutama bagi konsumen (masyarakat). Dampak positifnya adalah dapat menambah keuntungan (wajar) dan efisiensi ${ }^{40}$ bagi

38 Model struktur pasar dalam kasus ini adalah oligopoli, yakni model struktur pasar dimana hanya ada sedikit atau beberapa produsen/perusahaan di dalam suatu pasar. Jumlah perusahan yang ada di dalam struktur pasar oligopoli biasanya berkisar antara 2 (dua) hingga 10 (sepuluh) perusahaan. Dalam teori oligopoli, ada pula model Price Leadership yang menjelaskan bahwa perusahaan dominan mempunyai kekuatan sebagai price setter (penentu harga). Harga yang ditetapkan oleh perusahaan dominan kemudian akan diikuti oleh perusahaan-perusahaan lainnya sebagai price taker. Pada model ini, korelasi hanya berjalan satu arah, karena perubahan harga produk perusahaan yang tidak dominan tidak akan mempunyai reaksi terhadap harga perusahaan dominan. Putusan Perkara Nomor: 07/ KPPU-L/2007. Pesaing Carefour pada saat itu hanya berjumlah lima (5) di antaranya Matahari, Ramayana, Lion Superindo, Hero dan Yogya.

39 Kasus ini telah diputus oleh KPPU yang mana PT. Carrefour Indonesia diputus bersalah telah melakukan praktik monopoli yang menyebabkan persaingan usaha tidak sehat. Terlapor, PT. Carrefour Indonesia terbukti secara sah dan meyakinkan melanggar Pasal 17 ayat (1) dan Pasal 25 ayat (1) huruf a UU No. 5 Tahun 1999 melalui Putusan KPPU Nomor 09/KPPUL/2009 dengan denda sebesar Rp. 25.000.000.000,00 (dua puluh lima milyar rupiah).

40 Efisiensi ini dalam istilah ekonomi disebut sebagai efisensi produktif, yaitu suatu kondisi di mana perusahaan memproduksi barang dan jasa dengan biaya yang paling rendah atau tingkat produksi paling efisien, yang diindikasikan oleh kondisi di mana tingkat produksi berada pada tingkat biaya rata-rata per unit (average cost/AC) yang paling rendah. Catur Agus Saptono, Hukum Persaingan Usaha Economic Analysis of Law dalam 
pelaku usaha; sedangkan dampak negatifnya adalah harga barang menjadi tidak kompetitif dan tertutupnya kesempatan berusaha bagi pelaku usaha lain yang pada akhirnya mendistorsi mekanisme pasar yang wajar. Dampak yang ditimbulkan tersebut menunjukkan bahwa aksi korporasi tidak lagi hanya persoalan privat kalangan pelaku usaha, melainkan juga menjadi persoalan publik karena terdapat kepentingan umum yang potensial dirugikan. Pada titik inilah, aksi korporasi berkaitan erat dengan persaingan usaha yang sehat.

\section{Notifikasi dalam Aksi Korporasi: Sebelum atau Sesudah?}

Uraian terdahulu menunjukkan bahwa aksi korporasi bisa berdampak buruk bagi persaingan usaha. Hal demikian terjadi karena akan ada kemungkinan pemusatan pelaku usaha, yang dalam hal tertentu bisa menyebabkan posisi dominan dan dapat mengatur jumlah produksi dan peredaran barang. Salah satu cara menekan dampak negatif aksi korporasi tersebut adalah dengan mewajibkan pelaku usaha untuk melaporkan (notifikasi) aksi korporasinya kepada KPPU. Dengan begitu, akan diketahui apakah aksi korporasi yang dilakukan berdampak buruk atau tidak pada persaingan usaha.

Notifikasi atau pemberitahuan adalah penyampaian informasi resmi secara tertulis yang wajib dilakukan oleh pelaku usaha kepada KPPU atas penggabungan, peleburan dan pengambilalihan saham perusahaan yang berakibat nilai aset dan atau penjualannya melebihi jumlah tertentu. Pada umumnya notifikasi dapat dilakukan sebelum aksi korporasi dilakukan atau sesudahnya. Notifikasi yang dilakukan sebelum aksi korporasi disebut pra-notifikasi, dan notifikasi yang dilakukan sesudah aksi korporasi dinamakan post-notifikasi. Di Indonesia, yang berlaku adalah post-notifikasi. Hal ini tersirat dari definisi notifikasi atau pemberitahuan, yaitu penyampaian informasi resmi secara tertulis yang wajib dilakukan oleh pelaku usaha kepada KPPU atas penggabungan atau peleburan badan usaha, dan pengambilalihan saham perusahaan setelah penggabungan atau peleburan badan usaha atau pengambilalihan saham perusahaan

Pelaksanaan Merger (Kencana: Depok, 2017), hlm. 52. 
berlaku efektif secara yuridis. ${ }^{41}$

Di Indonesia, kewajiban notifikasi bagi perusahaan yang melakukan aksi korporasi sudah ada sejak terbit UU Persaingan Usaha (1999). Namun demikian, karena Pasal 29 ayat (1) UU tersebut mengatur notifikasi aksi korporasi bersifat lex imperfect ${ }^{42}$ yang berarti norma bersangkutan hanya dapat dilaksanakan setelah pemerintah menerbitkan Peraturan Pemerintah, maka untuk mengakomodasinya KPPU berinisiatif menerbitkan aturan tersendiri yakni Peraturan Komisi Persaingan Usaha Nomor 1 Tahun 2009 tentang Pra-Notifikasi Penggabungan, Peleburan, dan Pengambilalihan (Perkom No. 1 Tahun 2009) yang pada intinya memberikan kesempatan kepada pelaku usaha secara sukarela memberitahu kepada KPPU untuk mendapatkan penilaian mengenai rencana aksi korporasai. ${ }^{43}$ Dalam perkembangannya, Perkom ini tidak berlaku lama dan peraturan ini juga kurang efektif dipatuhi pelaku usaha. ${ }^{44}$ Dengan begitu, hadirnya Perkom tersebut sebenarnya mengisyaratkan bahwa semangat pranotifikasi aksi korporasi telah ada sejak lama.

Ketentuan tentang notifikasi kemudian menjadi lebih efektif setelah terbit PP No. 57 Tahun 2010 pada 20 Juli 2010 yang memberlakukan sistem post-notifikasi. Dalam PP ini, pelaku usaha

41 Lampiran Perkom No. 2 Tahun 2013.

42 Yakub Adi Krisanto, "Pengesahan Pelaksanaan Penggabungan, Peluburan dan Pengambilalihan (P3) dan Kedudukan Konsultasi dalam Hukum Persaingan Usaha”, Jurnal Hukum Prioris, 3, 1 (2012), hlm. 70.

43 Dalam konsep pembentukan peraturan perundang-undangan, Perkom tentang Pra-notifikasi sebetulnya keluar dari substansi norma Pasal 29 UU Persaingan Usaha sebab pasal tersebut mengatur notifikasi setelah aksi korporasi selesai dilaksanakan (post-notifikasi). Namun, kebijakan KPPU menurut Penulis perlu diapresiasi sebab kebijakan tersebut merupakan langkah insiatif untuk meminimalisir potensi pembatalan aksi korporasi yang lebih mengedepankan asas kemanfaatan.

44 Perkom No. 1 Tahun 2009 ditetapkan pada tanggal 13 Mei 2009. Pranotifikasi tidak bersifat mengikat kepada pelaku usaha yang berarti tidak ada akibat hukum jika pelaku usaha tidak melaksanakan penilaian KPPU atau tidak notifikasi aksi korporasinya. Perkom ini diketahui hanya menangani lima pemberitahuan. Laporan banyak dari Multi National Company yang menunjukkan bahwa mereka sudah terbiasa melakukan pra-notification untuk kegiatan penggabungan dan pengambilalihan. http://www.kppu. go.id/id/merger-dan-akuisisi/pra-notifikasi/, diakses 15/3/2019. 
wajib memberitahu aksi korporasinya secara tertulis paling lama 30 hari kerja sejak tanggal telah berlaku efektif secara yuridis aksi korporasi tersebut. ${ }^{45}$ PP ini sebenarnya masih mengadopsi sistem pra-notifikasi aksi korporasi secara sukarela sebagaimana dalam Perkom Pra-Notifikasi, yang disebut dengan istilah "konsultasi". ${ }^{46}$ Secara garis besar PP No. 57 Tahun 2010 mengatur empat hal, yaitu cara penilaian merger dan akuisisi yang menyebabkan praktik monopoli dan persaingan usaha tidak sehat; batas nilai notifikasi atau pemberitahuan; tata cara pemberitahuan; dan konsultasi. ${ }^{47}$ Sedangkan komponen penilaian notifikasi meliputi lima aspek, yakni konsentrasi pasar, hambatan masuk pasar, potensi perilaku anti persaingan, efisiensi, dan/atau kepailitan. ${ }^{48}$

Dengan demikian, perusahaan yang melakukan aksi korporasi perlu melakukan konsultasi dan notikasi. Konsultasi diperlukan bagi korporasi yang akan melakukan aksi korporasi, dan dengan begitu berarti sebelum (pra) aksi korporasiberlangsung; sedangkan notifikasi diperlukan sesudah (post) aksi korporasi selesai dilaksanakan. Namun demikian, sifat pelaksanaan keduanya berbeda. Jika konsultasi bersifat sukarela, artinya perusahaan dapat melakukannya tetapi juga dapat meninggalkannya, berbeda dengan notifikasi bersifat kewajiban, yang artinya tidak boleh ditinggalkan oleh perusahaan yang melakukan aksi korporasi.

Dalam praktik di dunia, kebanyakan negara sebenarnya menggunakan sistem pra-notifikasi aksi korporasi. Hal ini dibuktikan berdasarkan data Internasional Competition Network (ICN), bahwa hanya segelintir negara yang tidak menggunakan sistem pra-notifi-

45 Pasal 5 ayat (1) PP No. 57 Tahun 2010.

46 Pasal 1 angka 1 Perkom No. 11 Tahun 2010 tentang Konsultasi Penggabungan Atau Peleburan Badan Usaha Dan Pengambilalihan Saham Perusahaan: "Konsultasi adalah permohonan saran, bimbingan, dan/atau pendapat tertulis yang diajukan oleh Pelaku Usaha kepada Komisi atas rencana Penggabungan atau Peleburan Badan Usaha, dan Pengambilalihan Saham Perusahaan sebelum Penggabungan atau Peleburan Badan Usaha atau Pengambilalihan Saham Perusahaan berlaku efektif secara yuridis".

47 Komisi Pengawas Persaingan Usaha (KPPU-RI), "Laporan Tahun 2010”, hlm. 14.

48 Lihat Perkom No. 2 Tahun 2013. 
kasi di antaranya adalah Inggris dan Australia, ${ }^{49}$ selain juga Indonesia. Lalu timbul pertanyaan, apa keunggulan dan kelemahan sistem pranotifikasi aksi korporasi dan sistem post-notifikasi, dan mengapa banyak negara memakai sistem pra-notifikasi aksi korporasi ketimbang sistem post-notifikasi aksi korporasi? Untuk menjawab pertanyaan ini perlu dibahas dampak ketika sistem notifikasi dilakukan setelah aksi korporasi dan dampak ketika sistem notifikasi dilakukan sebelum aksi korporasi.

Pertama, sistem post-notifikasi. Dengan mengambil contoh kasus di Indonesia, sistem ini memiliki sejumlah permasalahan baik pada tataran filosofi maupun implementasi. Secara filosofis, sistem notifikasi dalam aksi korporasi pada dasarnya merupakan upaya mencegah timbulnya praktik monopoli dan persaingan usaha tidak sehat. Jika aksi korporasi ${ }^{50}$ mengakibatkan terjadinya praktik monopoli atau persaingan usaha tidak sehat sehingga berujung pada pembatalan, maka maksud notifikasi sebagai instrumen preventif telah hilang. Post-notifikasi di satu sisi dikatakan sederhana, namun menyimpan potensi ketidakpastian hukum bagi pelaku usaha itu sendiri serta tidak efektifnya instrumen pengawasan aksi korporasi.

Ketidakpastian hukum terhadap pelaku usaha terlihat ketika pelaku usaha telah mendapatkan persetujuan aksi korporasi

49 Inggris memang tidak mewajibkan pelaku usaha untuk melaporkan aksi merger akuisisi ke otoritas pengawas persaingan. Namun, otoritas pengawasan persaingan memiliki kewenangan untuk melakukan investigasi terhadap merger akuisisi yang berpotensi menghambat persaingan dan dapat berujung kepada keputusan pengadilan untuk membatalkan transaksi merger akuisisi tersebut. Sementara, Australia menganut sistem pelaporan sukarela, namun ACCC (KPPU Australia) dapat melakukan investigasi dan permohonan kepada pengadilan untuk menghentikan proses merger akuisisi yang dianggap dapat membahayakan iklim persaingan. Saptono, Hukum Persaingan Usaha, hlm. viii.

50 Perlu diketahui bahwa korporasi yang tidak memenuhi ambang batas nilai aset atau penjualan pada saat aksi korporasi bukan berarti bebas melaksanakan aksi korporasinya. Meski tidak dikenakan kewajiban notifikasi, aksi korporasi oleh korporasi yang tidak melewati ambang batas juga tetap tidak diperbolehkan mengakibatkan terjadinya praktik monopoli dan atau persaingan usaha tidak sehat, sebagaimana diatur dalam Pasal 28 UU Persaingan Usaha. 
dari Kemenkumham, ${ }^{51}$ lalu dibatalkan oleh KPPU karena dinilai adanya dugaan praktik monopoli dan persaingan usaha tidak sehat. Bagaimana mungkin aksi korporasi dapat dibatalkan? Sangat sulit rasanya untuk dilakukan pembatalan. Kalaupun dapat dibatalkan akan banyak pihak yang dirugikan khususnya para pemegang saham, karyawan atau pihak yang memiliki jabatan struktral penting di perusahannya. Faktanya, hingga sekarang belum ada aksi korporasi yang dibatalkan oleh KPPU. Secara tidak sadar sebenarnya dengan post-notifikasi artinya pelaku usaha dalam melakukan aksi korporasi harus melaksakan izin ganda, kepada Kemenkumham dan KPPU.

Sulitnya pembatalan aksi korporasi dapat dilihat pada Putusan KPPU Nomor 07/KPPU-L/2007 tentang akuisisi saham PT. Telekomunikasi Selular dan PT. Indosat, Tbk. ${ }^{52}$ oleh Temasek Holdings Pte. Ltd (selanjutnya disebut Temasek), yang merupakan perusahaan investasi milik Singapura. ${ }^{53}$ Perkara ini mulai bergulir di

51 Merger, akuisisi dan konsolidasi selama ini baru dianilisis dari aspek administratif dan prosedural untuk kepentingan pengesahan perubahan Anggaran Dasar dan Rumah Tangga oleh Departemen Hukum dan HAM, jadi pada saat ini sangatlah perlu membuat kajian yang mendalam terkait dengan ketentuan merger, akuisisi dan konsolidasi dalam perspektif Hukum Persaingan Usaha. Paulus Aluk Fajar Dwi Santo, "Merger, Akusisi dan Konsolidasi dalam Perspektif Hukum Persaingan Usaha”, Binus Business Review, 2, 1 (2011), hlm. 425.

52 Kegiatan telekomunikasi di Indonesia awalnya dikuasai oleh negara melalui Badan Usaha Milik Negara, yaitu PT. Telkom, Tbk. yang mana sahamnya dimiliki oleh pemerintah sebesar 51, 19\% dan memonopoli jasa layanan telekomunikasi domestik serta PT. Indosat, Tbk. ("Indosat") yang keseluruhan sahamnya diakuisisi oleh pemerintah pada tahun 1980 dan memonopoli layanan jasa telekomunikasi internasional. Putusan KPPU Nomor 07 / KPPU-L/ 2007, hlm. 8.

53 Sayangnya, saat KPPU menangani perkara kepemilikan silang pada Kelompok Usaha Temasek, Pemerintah masih belum menerbitkan Peraturan Pemerintah (PP) sebagaimana diamanatkan oleh UU Persaingan Usaha. Sementara praktek monopoli dan persaingan usaha tidak sehat yang ditimbulkan akibat aksi korporasi mulai bermunculan di pasar atau lebih parah lagi telah ada sejak disahkannya UU No. 5/1999 tersebut. Jika saja sudah terbit PP tersebut maka Temasek dapat dikenakan Pasal 28 atau 29 UU Persaingan Usaha yang mengatur aksi korporasi yang dapat mengakibatkan praktek monopoli dan atau persaingan usaha tidak sehat. Verry Iskandar, "Akuisisi Saham oleh Perusahaan Terafiliasi dalam Perspektif Hukum Persaingan Usaha”, Jurnal Persaingan Usaha, 5 (2011), hlm. 15. 
KPPU pada April 2007, empat tahun lebih setelah saham PT. Indosat, Tbk. diakuisisi oleh Temasek melalui anak perusahannya, KPPU menilai akibat akuisisi tersebut telah mengurangi tingkat persaingan di pasar dan merugikan konsumen telepon seluler. ${ }^{54}$ Kelompok usaha Temasek melalui Singapore Telecommunication (SingTel) menguasai saham PT. Telekomunikasi Seluler Indonesia (Telkomsel) sebesar 35\% dan secara bersama-sama menguasai PT. Indosat melalui Singapore Technologies Telemedia (STT) sebesar 40,8\%. Akibatnya, telah terjadi kepemilikan silang ${ }^{55}$ (cross ownership) kelompok usaha Temasek pada Indosat dan Telkomsel. Melalui diktum ke-empat ${ }^{56}$ putusan KPPU pada 19/11/2007, Temasek diperintahkan agar melepaskan kepemilikan sahamnya pada Telkomsel atau PT. Indosat, Tbk. Putusan tersebut telah dikuatkan oleh Pengadilan Negeri Jakarta Pusat dan Mahkamah Agung (MA) Republik Indonesia. ${ }^{57}$

Meskipun demikian, putusan KPPU tersebut secara yuridis

54 Kondisi excessive pricing dalam pasar jasa layanan seluler Indonesia mengakibatkan kerugian konsumen Indonesia atas tindakan kepemilikan silang yang dilakukan oleh Temasek bersama-sama dengan STT, STTC, AMHC, AMH, ICL, ICPL, SingTel, dan SingTel Mobile sejak tahun 2003 sampai dengan tahun 2006 telah menyebabkan kerugian konsumen sebesar Rp. 14.764.980.000.000,00 (empat belas triliun tujuh ratus enam puluh empat miliar sembilan ratus delapan puluh juta rupiah) dan maksimal sebesar Rp 30.808.720.000.000,00 (tiga puluh triliun delapan ratus delapan miliar tujuh ratus dua puluh juta rupiah). Putusan KPPU Nomor 07/KPPU-L/2007, hlm. 668 .

55 Kepemilikan saham silang diatur dalam Pasal 27 UU Persaingan Usaha dan sebenarnya juga telah diatur dan dinyatakan dilarang dalam UUPT 2007, hanya saja norma tersebut terletak pada bagian penjelasan Pasal 36 ayat (1).

56 Memerintahkan kepada Temasek Holdings, Pte. Ltd., bersama-sama Singapore Technologies Telemedia Pte. Ltd., STT Communications Ltd., Asia Mobile Holding Company Pte. Ltd, Asia Mobile Holdings Pte. Ltd., Indonesia Communication Limited, Indonesia Communication Pte. Ltd., Singapore Telecommunications Ltd., dan Singapore Telecom Mobile Pte. Ltd untuk menghentikan tindakan kepemilikan saham di PT. Telekomunikasi Selular dan PT. Indosat, Tbk. dengan cara melepas seluruh kepemilikan sahamnya di salah satu perusahaan yaitu PT. Telekomunikasi Selular atau PT. Indosat, Tbk. dalam waktu paling lama 2 (dua) tahun terhitung sejak putusan ini memiliki kekuatan hukum tetap. Amar putusan KPPU Nomor 07 / KPPU-L/2007, hlm, 689.

57 Iskandar, "Akuisisi Saham oleh Perusahaan Terafiliasi", hlm. 6. 
formil sulit untuk dieksekusi. Kesulitan tersebut dikarenakan, MA menghilangkan diktum keenam Putusan KPPU atas Putusan PN Jakarta Pusat mengenai perintah divestasi. Diktum keenam itu adalah perintah membatasi pelepasan saham untuk masing-masing calon pembeli maksimal 5 persen dan pembeli tidak boleh terafiliasi dengan kelompok usaha Temasek dalam bentuk apa pun. Padahal, salah satu esensi putusan KPPU justru terletak pada diktum keenam tersebut agar tidak lagi terjadi kepemilikan silang di Indosat dan Telkomsel. Putusan MA yang menghapus diktum tersebut justru membuka ruang kepada kelompok Temasek untuk tetap memiliki kedua perusahaan telekomunikasi itu dengan menjual sahamnya kepada afiliasinya. Terbukti, bahwa ketika masih dalam tahap pemeriksaan kasasi oleh Mahkamah Agung, Singapore Technologies Telemedia (STT) sebagai perusahaan dalam kelompok usaha Temasek telah mengalihkan saham PT. Indosat kepada Qatar Telecom. ${ }^{58}$ Jadi, bisa dikatakan bahwa putusan MA sebenarnya tidak mengakhiri kepemilikan saham silang oleh Temasek.

Sama halnya dengan kasus Temasek, Putusan KPPU Nomor 09/KPPU-L/2009 tentang akuisisi PT. Alfa Retailindo, Tbk. oleh PT. Carrefour Indonesia yang mana salah satu amar putusannya dalam diktum ketiga ${ }^{59}$ yakni pembatalan akuisisi juga dibatalkan oleh Pengadilan Negeri Jakarta Selatan. Dalam kasus ini KPPU sempat mengajukan kasasi kepada Mahkamah Agung, namun ditolak. ${ }^{60}$ Dengan penolakan tersebut, kepemilikan saham tetap ada pada Carrefour.

Sistem post-notifikasi yang berlaku di Indonesia saat ini jelas tidak efektif. Pertama, tiga bentuk notifikasi yang berlaku di Indonesia

58 Iskandar, "Akuisisi Saham oleh Perusahaan Terafiliasi”, hlm. 20.

59 Memerintahkan Terlapor, PT. Carrefour Indonesia untuk melepaskan seluruh kepemilikannya di PT. Alfa Retailindo, Tbk. kepada pihak yang tidak terafiliasi dengan PT. Carrefour Indonesia selambat-lambatnya satu tahun setelah putusan ini berkekuatan hukum tetap. Putusan KPPU Nomor 09/ KPPU-L/2009, hlm. 280.

60 https: / / finance.detik.com/berita-ekonomi-bisnis/d-1500466/kasasiditolak-ma-kppu-kalah-lawan-carrefour, "Kasasi Ditolak MA, KPPU Kalah Lawan Carrefour”, 23/11/2010, diakses 4/3/2019. 
dinilai tidak praktis karena dari segi konsultasi yang ditawarkan tidak bersifat mengikat kepada pelaku usaha untuk wajib berkonsultasi dan hasil konsultasi tidak memiliki kekuatan hukum apapun jika tidak dilaksanakan sehingga terkesan sia-sia. ${ }^{61}$ Kedua, post-notifikasi juga tidak jarang menimbulkan masalah terkait kasus keterlambatan notifikasi, ${ }^{62}$ misalnya perbedaan pandangan kapan tanggal berlaku efektif aksi korporasi, ketidaktahuan pelaku usaha kapan waktu yang tepat untuk melapor, apalagi ketika pelaku usaha sudah melakukan konsultasi yang mengira ia sudah melakukan kewajiban untuk lapor. Bahkan, KPPU pernah salah menentukan tanggal efektif aksi korporasi. Ketiga, penilaian dengan $\operatorname{syarat}^{63}$ (remedies), meski dimaksudkan sebagai upaya untuk melindungi pelaku usaha agar terhindar dari pembatalan aksi korporasi namun pada dasarnya sistem ini justru seolah-olah memperlihatkan bahwa hukum terkesan dapat ditawar, istilah yang biasa dikenal di Indonesia adalah "dinego". Terbukti bahwa belum pernah ada pendapat KPPU mengenai notifikasi yang memutus aksi korporasi tersebut terindikasi dugaan praktik monopoli. Dari analisa Penulis, KPPU hanya memutus

61 Walaupun konsultasi tidak bersifat mengikat sebagaimana ditentukan dalam Pasal 11 ayat (4) PP No. 57 Tahun 2010, namun dalam Lampiran Perkom No. 2 Tahun 2013 mengisyaratkan bahwa catatan berupa saran dan/atau bimbingan yang dikeluarkan oleh KPPU melalui konsultasi harus dipenuhi pelaku usaha. Hal ini menurut Penulis terkesan blunder karena disatu sisi konsultasi hanya bersifat sukarela tapi disisi yang lain konsultasi terkesan memaksa pelaku usaha.

62 Sejak PP No. 57 Tahun 2010 dibentuk hingga tahun 2018, kasus mengenai keterlambatan notifikasi aksi korporasi hanya terdapat 16 kasus. Penulis sempat menelaah satu per satu putusan yang didapat dari laman website KPPU, kebanyakan kasus keterlambatan tidak serta merta didasari atas keinginan pelaku usaha untuk menyembunyikan aksi korporasinya, faktor ketidaktahuan, salah menelaah ketentuan pasal, adanya tabrakan mengenai ketentuan kapan berlaku efektif aksi korporasi menjadi faktor dominan kasus keterlambatan.

63 Sistem remedies diatur dalam Perkom No. 2 Tahun 2013, remedies memberikan kesempatan (bersifat sukarela) kepada pelaku usaha untuk mengajukan proposal syarat (remedies) pada tahap konsultasi maupun post-notifikasi yang dinilai menimbulkan praktik monopoli dan persaingan usaha tidak sehat yang digunakan sebagai pertimbangan KPPU untuk meloloskannya menjadi tidak adanya dugaan praktik monopoli atau persaingan usaha tidak sehat dengan catatan yang harus dipenuhi oleh pelaku usaha. 
perkara-perkara keterlambatan melapor aksi korporasi saja. ${ }^{64}$

Sehubungan dengan itu, tiga poin yang dijabarkan di atas pada dasarnya berakar dari Peraturan Pemerintah (PP) yakni PP No. 57 Tahun 2010 yang diterbitkan atas amanat dari Pasal 29 ayat (2) UU Persaingan Usaha. Pasal 12 Undang-Undang Nomor 12 Tahun 2011 tentang Pembentukan Peraturan Perundang-Undangan menjelaskan bahwa materi muatan Peraturan Pemerintah berisi materi untuk menjalankan undang-undang sebagaimana mestinya. Maksud "menjalankan undang-undang sebagaimana mestinya" adalah penetapan Peraturan Pemerintah untuk melaksanakan perintah UndangUndang atau untuk menjalankan Undang-Undang sepanjang diperlukan dengan tidak menyimpang dan materi yang diatur dalam Undang-Undang yang bersangkutan. ${ }^{65}$

Beranjak pada pemahaman di atas, PP No. 57 Tahun 2010 telah keluar dari koridor fungsinya sebagai pelaksana UU, sebab PP tersebut telah memperluas makna Pasal 29 ayat (1) UU Persaingan Usaha dengan memunculkan sistem baru yakni sistem konsultasi. Begitupun dengan sistem remedies yang dimunculkan dalam Perkom No. 2 Tahun 2013. Sehingga, dalam pandangan hierarki peraturan perundang-undangan, dapat disimpulkan PP No. 57 Tahun 2010 dan Perkom No. 2 Tahun 2013 telah bertentangan dengan UU Persaingan Usaha. Jadi, menurut Penulis, sistem konsultasi dan remedies tidak memiliki kekuatan hukum mengikat. Dengan demikian, sistem notifikasi yang berlaku hari ini tidak mencerminkan kepastian hukum

64 Dalam aspek yuridis, suatu Peraturan Pemerintah tidak dapat mengubah materi yang ada dalam undang-undang yang dijalankannya, tidak dapat menambah, tidak mengurangi, dan tidak menyisipkan suatu ketentuan, serta tidak memodifikasi materi dan pengertian yang telah ada dalam undang-undang yang menjadi induknya (King Faisal Sulaiman, Teori Peraturan Perundang-Undangan dan Aspek Pengujinya [Jakarta: Thafa Media, 2017], hlm. 75). Berdasarkan hal tersebut, sebetulnya sanksi keterlambatan melapor tidak diatur dalam UU Persaingan Usaha, Pasal 29 ayat (2) UU Persaingan Usaha hanya mengatakan, "Ketentuan tentang penetapan nilai aset dan atau nilai penjualan serta tata cara pemberitahuan sebagaimana dimaksud dalam ayat (1) diatur dalam Peraturan Pemerintah”. Itu berarti sanksi terlambat notifikasi tidak semestinya ada.

65 Sulaiman, Teori Peraturan Perundang-Undangan, hlm. 72. 
didalamnya.

Meskipun demikian, hadirnya sistem remedies sebenarnya merupakan jembatan penghubung KPPU agar sedapat mungkin dapat turut andil untuk mempengaruhi aksi korporasi pelaku usaha akibat sulitnya melakukan pembatalan. Hal ini dipengaruhi oleh tidak adanya pengaturan mekanisme pembatalan aksi korporasi jika aksi korporasi dibatalkan atas dasar indikasi praktek monopoli. Walaupun sudah dibentuk sistem yang sedemikian rupa agar pelaku usaha tidak merugi,ternyata masih banyak pelaku usaha yang tidak melaporkan aksi korporasinya kepada KPPU, setidaknya terdapat sekitar 300 perusahaan. ${ }^{66}$ Akan tetapi, akhir-akhir ini KPPU hanya mengangkat 12 perkara keterlambatan notifikasi. ${ }^{67}$ Menurut Penulis, absennya pelaku usaha untuk melaporkan aksi korporasinya tidak luput dari faktor tidak praktisnya model notifikasi dan ketakutan pelaku usaha terhadap sanksi pembatalan yang akan dikenakan oleh KPPU.

Permasalahan dalam tataran implementasi dapat ditelisik melalui tinjauan kasus yakni Putusan KPPU Nomor 08-KPPUM/2012 mengenai keterlambatan melakukan pemberitahuan pengambilalihan saham PT. Andalan Satria Lestari (ASL) oleh PT. Bumi Kencana Eka Sejahtera (Terlapor). Dalam proses akuisisi ASL,

66 http: / ekonomi.kompas.com/read/2018/12/03/200800326/300-lebihperusahaan-tak-laporkan-keputusan merger-dan-akuisisi-ke-kppu, “300 Lebih Perusahaan Tak Laporkan Keputusan Merger dan Akuisisi ke KPPU”, 3/12/2018, diakses 2/3/2019. Di Indonesia sendiri, tren merger dan akuisisi di Indonesia melorot sejak empat tahun terakhir. Jumlah notifikasi tertinggi yakni pada 2013, yang mencapai 70 notifikasi, dengan 69 di antaranya notifikasi. Sejak itu trennya terus menurun. Dari 59 (2014), 53 (2015) dan 50 (kuartal III/2016). Dalam hal notifikasi merger, sistem notifikasi merger Indonesia memiliki kelemahan, mengingat rezim notifikasi yang sudah berlaku adalah post-notifikasi. Dalam rezim ini, pelaku merger cenderung kurang kooperatif, karena hampir mustahil merger yang dinotifikasi di-tolak mengingat pertimbangan ekonomi yang sangat besar. Komisi Pengawas Persaingan Usaha, "Tahun Berburu Kartel Laporan Tahunan 2016”, hlm. 56-57.

67 https: / / www.hukumonline.com/berita/baca/1t5d525a226a349 / bertahun-tak-notifikasi-merger--ini-12-transaksi-merger-terancam-dendarp25-milyar/, "Bertahun Tak Notifikasi Merger, Ini 12 Transaksi Merger Terancam Denda Rp25 Milyar”, 13/8/2019, diakses 13/8/2019. 
dilakukan dua tahap yang berlaku efektif tanggal 27 Februari 2012 untuk akuisisi tahap pertama, dan 27 April 2012 untuk akuisisi tahap kedua. KPPU menilai bahwa pemberitahuan seharusnya dilakukan setelah 30 hari berlaku efektif pengambilan saham tahap pertama yakni jatuh pada tanggal 10 April 2012. Namun, terlapor baru melakukan notifikasi tanggal 25 Mei 2012 dan dinyatakan terlambat selama 31 hari kerja.

Alasan KPPU mengapa Terlapor seharusnya melakukan notifikasi pada tahap pertama akuisisi berlaku efektif karena KPPU menilai sudah terjadi perpindahan pengendalian dari ASL kepada Terlapor. Sementara Terlapor berdalih bahwa akuisisi tahap pertama belum memosisikan Terlapor sebagai pengendali ASL. KPPU dalam menentukan tanggal berlaku efektif aksi korporasi pada tahap pertama menggunakan Persetujuan Menkumham atas anggaran dasar sebagai bukti akuisisi tahap pertama. Sedangkan pada proses pengambilalihan saham ASL tahap kedua, KPPU menggunakan dokumen penerimaan pemberitahuan Menkumham sebagai bukti.

Dari kasus di atas, diketahui bahwa ada perbedaan pandangan dalam menentukan tanggal wajib lapor. Padahal, jelas sekali bahwa esensi dari kewajiban melapor transaksi akuisisi adalah ketika pelaku usaha sudah menjadi pengendali atas perusahaan yang diakuisisinya. ${ }^{68}$ KPPU juga dinilai tidak konsisten menetapkan tanggal efektif akuisisi yang mana seharusnya tanggal efektif secara yuridis dari pengambilalihan (baik disertai perubahan anggaran dasar maupun tidak disertai perubahan anggaran dasar) adalah tanggal pemberitahuan diterima Menkumham. ${ }^{69}$ Sedangkan, KPPU menyatakan berlaku efektif akuisisi tahap pertama adalah tanggal persetujuan Menkumham atas perubahan anggaran dasar. Sebetulnya, akuisisi tahap pertama telah dilaporkan oleh PT. Dian Swastika Sentosa Tbk, yang merupakan induk perusahaan dari

68 Lampiran Perkom No. 2 Tahun 2013 menyebutkan bahwa pengambilalihan adalah perbuatan hukum yang dilakukan oleh Pelaku Usaha untuk mengambilalih saham badan usaha yang mengakibatkan beralihnya pengendalian atas badan usaha tersebut.

69 Lihat Pasal 133 UU Nomor 40 Tahun 2007 tentang Perseroan Terbatas pada bagian penjelasan huruf (b). 
Terlapor. $^{70}$

Kemudian, beranjak pada Putusan KPPU Nomor 07/KPPUM/2014 mengenai keterlambatan pemberitahuan pengambilalihan saham PT. HD Finance, Tbk oleh PT. Tiara Margo Trakindo (TMT). Pengambilalihan ini terjadi di bursa efek. KPPU menilai bahwa pengambilalihan HD Finance efektif secara yuridis pada tanggal 11 Maret 2013 yang mana seharusnya Terlapor wajib menyampaikan pemberitahuan pada tanggal 24 April 2013. Pada kenyataannya, Terlapor diketahui baru notifikasi pada tanggal 24 Juni 2013 sehingga lama keterlambatan terhitung selama 41 hari kerja. Kemudian, September 2013, KPPU menerbitkan hasil pemberitahuan pasca akuisisi dimana hasil penilaian tetap sama sewaktu konsultasi pada tanggal 11 Januari 2013. Akhirnya, Desember 2013, Terlapor menerima surat keterlambatan notifikasi. Padahal, tanggal 11 tahun 2013 tersebut nyatanya Terlapor belum menjadi pengendali baru yang masih mengakuisisi 45\% saham PT. HD Finance, Tbk.

Sebagaimana diatur dalam Lampiran Perkom No. 2 Tahun 2013 bahwa kewajiban untuk memberitahu aksi korporasi perseroan terbuka dilakukan paling lambat 30 (tiga puluh) harisejak tanggal surat keterbukaan informasi pengambilalihan saham perseroan terbuka. Namun, dalam prosesnya, pengambilalihan saham perusahaan terbuka juga mengacu pada Peraturan Bapepam (Badan Pengawas Pasar Modal dan Lembaga Keuangan), yang memiliki kewajiban untuk melakukan tender wajib yang merupakan satu kesatuan dari proses akuisisi. Dalam pandangan Terlapor, pengambilalihan berlaku efektif adalah sejak selesainya proses penawaran tender wajib yang diikuti dengan pengumuman keterbukaan informasi atas pelaksanaan penawaran tender wajib. Sehingga, kewajiban pemberitahuan mengenai pengambilalihan kepada KPPU mulai diperhitungkan sejak disampaikan laporan penyelesaian penawaran tender wajib kepada OJK (Otoritas Jasa Keuangan) yakni pada tanggal 27 Mei 2013.

70 Dalam Putusan, KPPU menganggap pemberitahuan tersebut belum lengkap sehingga dinyatakan belum lapor. Atas kasus tersebut, majelis komisi memutuskan Terlapor tidak terbukti terlambat dalam memberitahu aksi korporasinya. 
Dalam kasus ini, kembali memperlihatkan bahwa ada perbedaan penafsiran kapan suatu aksi korporasi dinyatakan berlaku efektif. Jika ditelisik kembali, dalam rentan waktu yang dijelaskan di atas, sebetulnya Terlapor telah menjalani pemberitahuan pasca akuisisi, barulah setelah itu muncul surat keterlambatan notifikasi. Penulis berpandangan, hal ini tidak relevan ketika kasus keterlambatan baru diangkat oleh investigator KPPU setelah dua bulan berselang Terlapor melakukan post-notifikasi sehingga terkesan hanya mencari kesalahan semata.

Jadi, berkaca dari dua kasus yang diuraikan di atas, post-notifikasi aksi korporasi dalam sejumlah kasus yang diangkat KPPU sebenarnya memperkarakan korporasi yang sudah beriktikad baik untuk melapor yang dinilai tidak substantif untuk memperkarakan hal yang demikian. Seharusnya, akan lebih kontekstual ketika KPPU fokus menjerat pelaku usaha yang benar-benar tidak melakukan notifikasi atau bahkan berusaha menyembunyikan transaksi aksi korporasinya.

Lalu, apa dampaknya jika sebelum aksi korporasi? Pertama, pra-notifikasi akan mempermudah mengeksekusi penilaian KPPU ketika aksi korporasi dinyatakan berpotensi menimbulkan praktik monopoli sebab aksi korporasi belum dilaksanakan. Dengan mudahnya mengeksekusi penilaian KPPU atas aksi korporasi yang dinilai buruk terhadap iklim persaingan, maka tujuan pencegahan timbulnya praktik monopoli dapat terlaksana sebab aksi korporasi tersebut belum sah secara hukum.

Kemudian, pra-notifikasi secara otomatis menjadi angin segar bagi pelaku usaha dalam menjalankan usahanya sebab ancaman sanksi pembatalan aksi korporasi bagi pelaku usaha tidak lagi bakal terjadi. Pra-notifikasi dipastikan dapat mencerminkan kepastian hukum sebab pelaku usaha yang akan notifikasi tidak bakal dibatalkan dengan demikian secara simultan mengeliminasi sistem izin ganda yang selama ini dilakukan pelaku usaha. ${ }^{71}$ Boleh jadi

71 Dari tinjauan keseluruhan pasal dalam UU Persaingan Usaha, sanksi hukum pembatalan aksi korporasi sebetulnya tidak disebutkan secara eksplisit dikenakan bagi pelanggaran pasal pasal 29 UU Persaingan Usaha. Hal ini 
sanksi pembatalan aksi korporasi hanya sebagai pajangan di UU Persaingan Usaha. Seperti halnya perintah divestasi dengan jangka waktu yang telah ditentukan sebagaimana dalam diktum putusan kasus Temasek Holding menimbulkan pertanyaan, bagaimana kalau seandainya dalam jangka waktu tersebut, belum ada pelaku usaha yang mau membeli saham tersebut? sementara UUPT 2007 tidak mengatur secara eksplisit mengenai hal demikian bahkan aturan mengenai divestasi saham karena pembatalan aksi korporasi dalam aspek persaingan usaha.

Kedua, pra-notifikasi mengaplikasikan dua pasal dalam UU No. 40 Tahun 2007 tentang Perseroan Terbatas (UUPT 2007) yang mengamini pentingnya persaingan usaha yang sehat yakni dalam ketentuan Pasal 126 ayat (1) UUPT 2007 beserta penjelasan pasalnya, yang mana aksi korporasi pada intinya wajib memperhatikan persaingan usaha yang sehat dan harus juga dicegah kemungkinan terjadinya monopoli atau monopsoni dalam berbagai bentuk yang merugikan masyarakat $^{72}$ dan dalam penjelasan Pasal 36 $6^{73}$ UUPT 2007 yang

diamini dalam Pasal 47 ayat (2) UU Persaingan Usaha, tidak ada satupun norma yang menentukan bahwa pelanggaran pada pasal 29 dikenakan sanksi pembatalan. Penulis sangat meyakini bahwa memang semangat hadirnya pasal 29 dimaksudkan sebagai langkah hukum preventif (pencegahan). Sanksi pembatalan aksi korporasi hanya terdapat pada Perkom No. 2 Tahun 2013. Dalam pandangan Penulis, sebetulnya tidak akan pernah terjadi yang namanya pembatalan aksi korporasi dikarenakan peraturan perundangundangan di Indonesia hingga kini tidak mengatur lebih jelas bagaimana mekanisme pembatalan aksi korporasi dalam segi persaingan usaha.

72 Sebelum UUPT 2007 diterbitkan, kesadaran akan persaingan yang sehat sudah tampak bahkan jauh sebelum UU Persaingan Usaha dibentuk. Hal ini ditunjukkan dalam Pasal 104 UU No. 1 Tahun 1995 tentang Perseroan Terbatas yang menyatakan aksi korporasi harus memperhatikan persaingan sehat, ditambah dengan penjelasan pasal 104 yang menyatakan bahwa aksi korporasi harus dicegah kemungkinan terjadi monopoli atau monopsoni dalam berbagai bentuk yang merugikan rakyat.

73 Pada prinsipnya, pengeluaran saham adalah suatu upaya pengumpulan modal, maka kewajiban penyetoran atas saham seharusnya dibebankan kepada pihak lain. Demi kepastian, Pasal ini menentukan bahwa Perseroan tidak boleh mengeluarkan saham untuk dimiliki sendiri. Larangan tersebut termasuk juga larangan kepemilikan silang (cross holding) yang terjadi apabila Perseroan memiliki saham yang dikeluarkan oleh Perseroan lain yang memiliki saham Perseroan tersebut, baik secara langsung maupun 
menentukan pelarangan kepemilikan saham silang seperti halnya pada kasus Temasek Holding yang telah dijabarkan sebelumnya.

Ketiga, pra-notifikasi juga dapat mencegah pelaku usaha terjerat Pasal $25^{74}$ tentang posisi dominan, Pasal $26^{75}$ tentang jabatan rangkap dan Pasal $27^{76}$ tentang pemilikian saham ${ }^{77}$ UU Persaingan

tidak langsung. Pengertian kepemilikan silang secara langsung adalah apabila Perseroan pertama memiliki saham pada Perseroan kedua tanpa melalui kepemilikan pada satu "Perseroan antara" atau lebih dan sebaliknya Perseroan kedua memiliki saham pada Perseroan pertama. Pengertian kepemilikan silang secara tidak langsung adalah kepemilikan Perseroan pertama atas saham pada Perseroan kedua melalui kepemilikan pada satu "Perseroan antara" atau lebih dan sebaliknya Perseroan kedua memiliki saham pada Perseroan pertama.

74 (1) Pelaku usaha dilarang menggunakan posisi dominan baik secara langsung maupun tidak langsung untuk: a. menetapkan syarat-syarat perdagangan dengan tujuan untuk mencegah dan atau menghalangi konsumen memperoleh barang dan atau jasa yang bersaing, baik dari segi harga maupun kualitas; atau b. membatasi pasar dan pengembangan teknologi; atau c. menghambat pelaku usaha lain yang berpotensi menjadi pesaing untuk memasuki pasar bersangkutan. (2) Pelaku usaha memiliki posisi dominan sebagaimana dimaksud ayat (1) apabila: a. satu pelaku usaha atau satu kelompok pelaku usaha menguasai 50\% (lima puluh persen) atau lebih pangsa pasar satu jenis barang atau jasa tertentu; atau b. dua atau tiga pelaku usaha atau kelompok pelaku usaha menguasai $75 \%$ (tujuh puluh lima persen) atau lebih pangsa pasar satu jenis barang atau jasa tertentu.

75 Seseorang yang menduduki jabatan sebagai direksi atau komisaris dari suatu perusahaan, pada waktu yang bersamaan dilarang merangkap menjadi direksi atau komisaris pada perusahaan lain, apabila perusahaanperusahaan tersebut: a. berada dalam pasar bersangkutan yang sama; atau b. memiliki keterkaitan yang erat dalam bidang dan atau jenis usaha; atau c. secara bersama dapat menguasai pangsa pasar barang dan atau jasa tertentu, yang dapat mengakibatkan terjadinya praktek monopoli dan atau persaingan usaha tidak sehat.

76 Pelaku usaha dilarang memiliki saham mayoritas pada beberapa perusahaan sejenis yang melakukan kegiatan usaha dalam bidang yang sama pada pasar bersangkutan yang sama, atau mendirikan beberapa perusahaan yang memiliki kegiatan usaha yang sama pada pasar bersangkutan yang sama, apabila kepemilikan tersebut mengakibatkan: a. satu pelaku usaha atau satu kelompok pelaku usaha menguasai lebih dari 50\% (lima puluh persen) pangsa pasar satu jenis barang atau jasa tertentu; b. dua atau tiga pelaku usaha atau kelompok pelaku usaha menguasai lebih dari 75\% (tujuh puluh lima persen) pangsa pasar satu jenis barang atau jasa tertentu.

77 Ditilik lebih dalam, Penulis berpandangan bahwa sebetulnya isi penjelasan Pasal 36 UUPT tentang larangan kepemilikan saham silang memiliki 
Usaha. Hal ini dilatarbekalangi bahwa kegiatan aksi korporasi sebetulnya merupakan salah satu faktor pemicu terjadinya bentuk kegiatan yang dilarang dalam pasal 25, 26, dan 27 tersebut. Dengan pra-notifikasi sebetulnya akan memeriksa unsur yang terdapat dalam pasal-pasal tersebut. Dengan demikian, hal ini berdampak positif untuk efisiensi biaya, maksudnya perkara praktik monopoli tentu akan semakin berkurang sebab gejala tersebut dapat dideteksi sejak dini melalui pra-notifikasi aksi korporasi sehingga biaya yang harus dikeluarkan dalam proses penanganan perkara akan menjadi lebih hemat, mencegah kerusakan pasar dan terwujudnya masyarakat yang tertib.

Keempat, pra-notifikasi juga akan memudahkan KPPU mendapatkan data dan informasi untuk memonitoring dan mengontrol perilaku pelaku usaha di pasar yang digunakan untuk memberikan rekomendasi dan saran yang akurat kepada pemerintah terkait kondisi industri yang melakukan penggabungan, peleburan, pengambilalihan sebab selama ini KPPU belum memiliki data akurat mengenai hal tersebut.

Terakhir, menyudahi problematika sebagaimana telah diuraikan dalam analisis kasus putusan keterlambatan aksi korporasi, di antaranya, perbedaan penafsiran kapan pelaku usaha wajib lapor, kesalahan KPPU dalam menentukan tanggal wajib lapor, tabrakan regulasi atas berlaku efektif aksi korporasi, bahkan mengeleminasi kasus keterlambatan yang memperkarakan pelaku usaha yang beritikad baik untuk melapor. Perkara keterlambatan pun tidak terlepas dari berbelit-belitnya sistem notifikasi akibat munculnya sistem

keterkaitan erat dengan Pasal 27 UU Persaingan Usaha tentang larangan memiliki saham mayoritas. Walaupun penjelasan Pasal 36 UUPT tidak terlalu jelas menyebutkan alasan mengapa kepemilikan saham silang dilarang bahkan tidak menentukan bagaimana bentuk kepemilikan saham silang yang dilarang, namun melalui Pasal 27 UU Persaingan Usaha dapat menjadi unsur pelengkap seperti apa kepemilikan saham yang dilarang. Dengan demikian, adanya pra-notifikasi aksi korporasi setidaknya dapat mencegah pelaku usaha terjerat dalam Pasal 27 UU Persaingan Usaha. Maka dari itu, instrumen hukum yang relevan untuk menilai aksi korporasi dalam aspek persaingan usaha adalah dengan melakukan pra-notifikasi aksi korporasi kepada KPPU. 
konsultasi dan remedies yang tidak jarang membingungkan pelaku usaha. Dengan pra-notifikasi maka dua sistem tersebut tidak akan muncul lagi.

Dengan demikian, berdasarkan uraian mengenai dampak postnotifikasi dan pra-notifikasi, sudah dapat dilihat jelas bahwa pranotifikasi lebih dominan berdampak positif dibanding post-notifikasi yang hampir setiap bagiannya berdampak negatif. Sehingga, pranotifikasi relevan diterapkan dalam UU Persaingan Usaha dibanding post-notifikasi.

Adapun kontruksi pra-notifikasi aksi korporasi yang Penulis tawarkan adalah pertama, notifikasi harus dilakukan pelaku usaha sebelum diadakan Rapat Umum Pemegang Saham (RUPS). Pranotifikasi tidak mematok batasan waktu yang ditentukan untuk melapor asalkan dilakukan sebelum RUPS dilakukan. Jika pelaku usaha tidak dibenarkan melakukan aksi korporasi maka pelaku usaha berhak membuat permohonan seperti layaknya penilaian dengan syarat (remedies) yang mana KPPU berhak mengeluarkan rekomendasi yang harus dipenuhi pelaku usaha agar memperoleh izin. Kedua, adapun bentuk izin ini dirancang berupa penetapan yang dituangkan dalam sebuah putusan yang diputus oleh majelis komisi yang memiliki kekuatan hukum yang mengikat, bukan berupa pendapat komisi seperti yang masih diterapkan sekarang. Dengan begitu, putusan tersebut mengikat secara hukum dan dapat dikasasi di MA jika pelaku usaha tidak puas dengan putusan KPPU. Ketiga, Penulis juga mengusulkan agar dibentuk sinergi antara KPPU, OJK, dan Kemenkumham dengan cara mewajibkan pelaku usaha untuk memberitahu rencana aksi korporasinya kepada KPPU sebelum mendapat persetujuan atau pengesahan dari Kemenkumham dan/atau OJK. Dengan kata lain, putusan KPPU menjadi syarat wajib pengesahan aksi korporasi. Dengan begitu, dapat dipastikan tidak akan ada lagi pelaku usaha yang terlambat melaporkan aksi korporasinya sehingga pencegahan serta persaingan usaha yang sehat dapat tewujud. 


\section{Kesimpulan}

Artikel ini menyimpulkan, pertama, aksi korporasi meliputi penggabungan (merger), peleburan (konsolidasi), dan pengambilalihan saham perseroan (akuisisi) berpengaruh terhadap persaingan usaha karena aksi korporasi memiliki dua efek negatif terhadap persaingan usaha, yakni terciptanya atau bertambahnya konsentrasi pasar yang dapat menyebabkan harga produk semakin tinggi dan kekuatan pasar (market power) pelaku usaha menjadi semakin besar yang dapat mengancam pebisnis kecil. Kedua, notifikasi aksi korporasi merupakan instrumen hukum yang penting dalam mencegah praktik monopoli dan persaingan usaha tidak sehat karena notifikasi dapat meminimalisasi potensi kecurangan pelaku usaha dan mencegah kerusakan pasar. Ketiga, sebagai instrumen yang penting dalam mencegah praktik monopoli maka sistem notifikasi sesudah aksi korporasi, atau disebut post-notifikasi, yang saat ini berlaku di Indonesia, sudah tidak relevan diterapkan untuk selanjutnya perlu diganti dengan sistem pra-notifikasi aksi korporasi yang jelas lebih efektif sebab konsekuensi ketika aksi korporasi berpotensi mengurangi persaingan akan mudah dicegah karena aksi korporasi belum selesai dilaksanakan.

\section{Daftar Pustaka}

\section{Artikel/Buku/Laporan}

Asshiddiqie, Jimly. Pengantar Ilmu Hukum Tata Negara. Depok: Rajawali Pers, cetakan kesembilan, 2017.

Deliarnov. Perkembangan Pemikiran Ekonomi Edisi Ketiga. Jakarta: Rajawali Pers, cetakan kesembilan, 2015.

Http: / / ekonomi.kompas.com/ read/ 2018/12/03/ 200800326/300-

lebih-perusahaan-tak-laporkan-keputusan merger-dan-akuisisike-kppu. "300 Lebih Perusahaan Tak Laporkan Keputusan Merger dan Akuisisi ke KPPU”, 3/12/2018. Diakses2/3/2019. Https: / / finance.detik.com/berita-ekonomi-bisnis / d-1500466/ kasasi-ditolak-ma-kppu-kalah-lawan-carrefour, "Kasasi Ditolak MA, KPPU Kalah Lawan Carrefour”, 23/11/2010. Diakses 
4/3/2019.

Http: / / www.kppu.go.id/id/merger-dan-akuisisi/pra-notifikasi/. Diakses 15/3/2019.

Https: / / www.hukumonline.com/berita/baca/lt5d525a226a349/

bertahun-tak-notifikasi-merger--ini-12-transaksi-mergerterancam-denda-rp25-milyar/. "Bertahun Tak Notifikasi Merger, Ini 12 Transaksi Merger Terancam Denda Rp25 Milyar”, 13/8/2019. Diakses 13/8/2019.

Is, Muhamad Sadi. Hukum Persaingan Usaha di Indonesia KPPU Sebagai Upaya Penguatan Lembaga Komisi Pengawas Persaingan Usaha. Malang: Setara Press, 2016.

Iskandar, Verry. "Akuisisi Saham oleh Perusahaan Terafiliasi dalam Perspektif Hukum Persaingan Usaha”. Jurnal Persaingan Usaha Edisi, 5 (2011): 1-29.

Krisanto, Yakub Adi. "Pengesahan Pelaksanaan Penggabungan, Peluburan dan Pengambilalihan (P3) dan Kedudukan Konsultasi dalam Hukum Persaingan Usaha”. Jurnal Hukum Prioris, 3, 1 (2012): 61-81.

Lubis, Andi Fahmi, dkk. Hukum Persaingan Usaha Antara Teks \& Konteks. Jakarta: KPPU, 2009.

Margono, Suyad. Hukum Anti Monopoli. Jakarta: Sinar Grafika, cetakan kedua, 2013.

Meyliana, Devi. Hukum Persaingan Usaha Studi Konsep Pembuktian Terhadap Perjanjian Penetapan Harga dalam Persaingan Usaha. Malang: Setara Press, 2013.

Nugroho, Susanti Adi. Hukum Persaingan Usaha di Indonesia dalam Teori dan Praktik serta Penerapan Hukumnya. Jakarta: Prenadamedia Group, cetakan ketiga, 2018.

Republik Indonesia, Komisi Pengawas Persaingan Usaha. "Laporan Tahun 2010".

Republik Indonesia, Komisi Pengawas Persaingan Usaha. "Tahun Berburu Kartel Laporan Tahunan 2016”.

Rihi, Megawati, dan I Ketut Sudantra. "Merger dalam Hubungannya dengan Persaingan Usaha Tidak Sehat". Kertha Semaya: Journal Ilmu Hukum, 1, 4 (2013): 1-5. 
Saptono, Catur Agus. Hukum Persaingan Usaha Economic Analysis of Law dalam Pelaksanaan Merger. Kencana: Depok, 2017.

Santo, Paulus Aluk Fajar Dwi. "Merger, Akusisi dan Konsolidasi dalam Perspektif Hukum Persaingan Usaha". Binus Business Review, 2, 1 (2011): 423-433. DOI: 10.21512/bbr.v2i1.1149

Sulaiman, King Faisal. Teori Peraturan Perundang-Undangan dan Aspek Pengujinya. Jakarta: Thafa Media, 2017.

Sutrisno dan Sumarsih. "Dampak Jangka Panjang Merger dan Akuisisi Terhadap Pemegang Saham di BEJ Perbandingan Akuisisi internal dan Eksternal”. Jurnal Akuntansi dan Auditing Indonesia, 8, 2, 2004: 189-210.

Tarigan, Pivi Princifal Yosefa dan Wahyu Ario Pratomo. "Analisis Dampak Merger dan Akuisisi Terhadap Abnormal Return dan Kinerja Keuangan Pada Perusahaan yang Terdaftar di Bursa Efek Indonesia”. Jurnal Ekonomi dan Keuangan, 3, 3 (2015): 200-212.

Usman, Rachmadi. Hukum Persaingan Usaha di Indonesia. Jakarta:

Sinar Grafika, 2013.

Usman, Rachmadi. Hukum Acara Persaingan Usaha di Indonesia. Jakarta: Sinar Grafika, 2013.

Widayat, Utoyo. "Beberapa Dimensi Merger dan Akuisisi”. Akuntansi Krida Wacana, 5, 3, 2005: 271-300.

\section{Peraturan dan Putusan Hukum}

Republik Indonesia. Undang-Undang Nomor 40 Tahun 2007 tentang Perseroan Terbatas.

Republik Indonesia. Undang-Undang Nomor 5 Tahun 1999 tentang Larangan Praktek Monopoli dan Persaingan Usaha Tidak Sehat.

Republik Indonesia. Peraturan Pemerintah Nomor 57 Tahun 2010 tentang Penggabungan atau Peleburan Badan Usaha dan Pengambilalihan Saham Perseroan Perusahaan yang Dapat Mengakibatkan Praktek Monopoli dan Persaingan Usaha Tidak Sehat.

Republik Indonesia, Komisi Pengawas Persaingan Usaha. Peraturan

Nomor 2 Tahun 2013 tentang Perubahan Ketiga atas Peraturan 
Komisi Pengawas Persaingan Usaha Nomor 13 Tahun 2010 tentang Pedoman Pelaksanaan tentang Penggabungan atau Peleburan Badan Usaha dan Pengambilalihan Saham Perusahaan yang Dapat Mengakibatkan Terjadinya Praktik Monopoli dan Persaingan Usaha Tidak Sehat.

Republik Indonesia, Komisi Pengawas Persaingan Usaha. Peraturan

Nomor 11 Tahun 2010 tentang Konsultasi Penggabungan atau Peleburan Badan Usaha dan Pengambilalihan Saham Perusahaan.

Republik Indonesia, Komisi Pengawas Persaingan Usaha. Putusan KPPU Nomor 09/KPPU-L/2009.

Republik Indonesia, Komisi Pengawas Persaingan Usaha. Putusan Perkara Nomor 02 / KPPU-L/ 2005.

Republik Indonesia, Komisi Pengawas Persaingan Usaha. Putusan KPPU Nomor 07/KPPU-L/ 2007.

Republik Indonesia, Komisi Pengawas Persaingan Usaha. Putusan KPPU Nomor 08-KPPU-M/ 2012.

Republik Indonesia, Komisi Pengawas Persaingan Usaha. Putusan KPPU Nomor 07 / KPPU-M/2014. 